\title{
James Chatham.
}

THE death of Mr James Chatham, one of the most distinguished actuaries of his day, calls for more than a passing remark, although with the lapse of time he was but little known personally to the present generation.

Born in Edinburgh in 1857 and educated here, it was not originally intended that he should follow an insurance career. He entered a merchant's office in Leith and remained there for some years. At the age of twenty-two he was offered and accepted a post in the Head Office of The Scottish Equitable Life Assurance Society, where for fourteen years he was assistant to that great actuary, Dr T. B. Sprague. In I 893 he received his first official appointment, that of an Assistant-Actuary to the Edinburgh Life Assurance Company. Then followed, in I895, further promotion, when he became Secretary and Actuary, and second officer, of The Scottish Life Assurance Company-a post which suited him admirably and gave full scope to his great talents.

A Fellow of the Statistical Society and also a Fellow, by examination, of both the Faculty and the Institute of Actuaries, he gained the first prize in two open competitions of the latter body-in I 890 the one offered by Dr Sprague, and in 1895 the Messenger Prize, for the best essays on Mortality Experiences and Valuation Methods respectively. The Journal of the Institute of Actuaries and the Transactions of the Faculty of Actuaries contain ample evidence of the value of his contributions to actuarial science, which are too numerous to mention, but his name will always be associated with two developments in life assurance practice. The first relates to the valuation of the liabilities of an office, and the second to the preparation of renewal premium receipts and notices. By the methods he devised the former can be accomplished in as many days as it used to take months; and the latter in as many hours as it used to take weeks. This second reform consisted of the adaptation, in 1904, of the addressograph to the printing of receipts, etc.-a practice which has spread, it is believed, all over the world.

James Chatham was by no means only an actuary. He was an all-round capable man of business: an able administrator, an authority on investments, a wise counsellor, and a man of high personal character.

It was these qualifications that, in 1906, led the Directors of the North British and Mercantile Insurance Company to appoint him Manager of 
the Company in Edinburgh. This important post he held only for some six years, as unfortunately his health had become impaired and necessitated his retirement.

On his resignation he went to live at Melrose, on Tweedside, where for more than twenty years he led a pleasant, health-restored life, contentedly retired from the arena of official life.

He was elected a Fellow of the Society in I 899, and died after a short illness on December 28, 1934.

L. P. O. 